\title{
Water Management in the Urban Cultural Heritage of Myanmar
}

\section{Elizabeth Moore', U San Win² and Pyiet Phyo Kyaw ${ }^{3}$}

\begin{abstract}
This article assesses indigenous perceptions of water through a comparison of the water management strategies at three ancient sites located in different ecological zones of Myanmar. Two of our examples are in the high-rainfall regions of Lower Myanmar: Thagara in the Dawei River valley flanked by mountains on the east and west, and Kyaikkatha on delta lands at the egress of the Sittaung River. We contrast these adaptations with the micro-exploitation of the scarce water resources at Bagan (also spelled Pagan) in the arid zone of Upper Myanmar. In the southern wet regions, despite the different geographical setting of Thagara and Kyaikkatha, the focus was on drainage and control. Multiple ramparts and moats were used to conserve the scarce water in the dry months between December and April and control the heavy floods of the rainy months between May to November. At Bagan, sited directly on the broad Ayeyarwady River, water management of inland streams and seasonal lakes maximised the gentle slope of the plain while also coping with intermittent flash floods in the rainy months. The sites of Thagara, Kyaikkatha, and Bagan demanded specific adaptations but are alike in the absence of extensive transformation of the landscape. This balance of manmade and natural elements provides common ground despite their variable size and urbanised extent, ecological setting, and occupational sequence to highlight the shared significance of water management in their longterm urban success.
\end{abstract}

KEYWORDS: Myanmar, water management, Thagara, Kyaikkatha, Bagan (Pagan)

\section{INTRODUCTION}

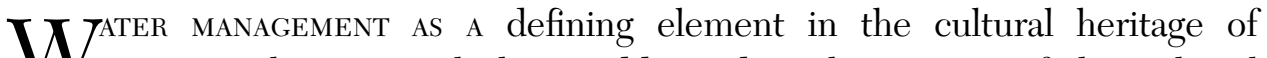
Myanmar has primarily been addressed in the context of the political and religious change giving rise to early Buddhist Pyu Ancient Cities (c.200 BC to 900 AD) where extensive but small-scale hydraulic engineering at Halin, Beikthano and Sri Ksetra accompanied a transformational expansion of the wet-rice cultivation (UNESCO 2014: 29, 56, 16). Scholars continue to debate the precise mechanisms of the massive walled Pyu Ancient Cities of Halin (540 ha) in Sagaing Region, Beikthano (900 ha) in Magwe Region, and Sri 
Ksetra (1840 ha) in Bago Region but concur on the use of multiple means to manage water resources from the exploitation of seasonal ponds, to canals, to encircling moats and walls (Hudson and Lustig 2008; Stargardt et al. 2012). Despite circa 5000+ mm rainfall per annum versus circa 750-1250 mm per annum at the Pyu Ancient Cities, a similar list of traits - seasonal ponds and built structures such as walls and canals - is seen at the smaller sites in the south such as Thagara ( $c$. ninth to seventeenth century AD; 243 ha) in the Tanintharyi Region, and Kyaikkatha (c. sixth to thirteenth century AD; 269 ha) in the Mon State (Fig. 1). At these sites, elevated mounds surrounded by agricultural land, water was managed to maximise land slope for drainage, water conservation, and cultivation (e.g. Aung Myint 1998: 104, Moore and San Win 2007, Moore and Than Swe 2006; San Win 2005). ${ }^{1}$

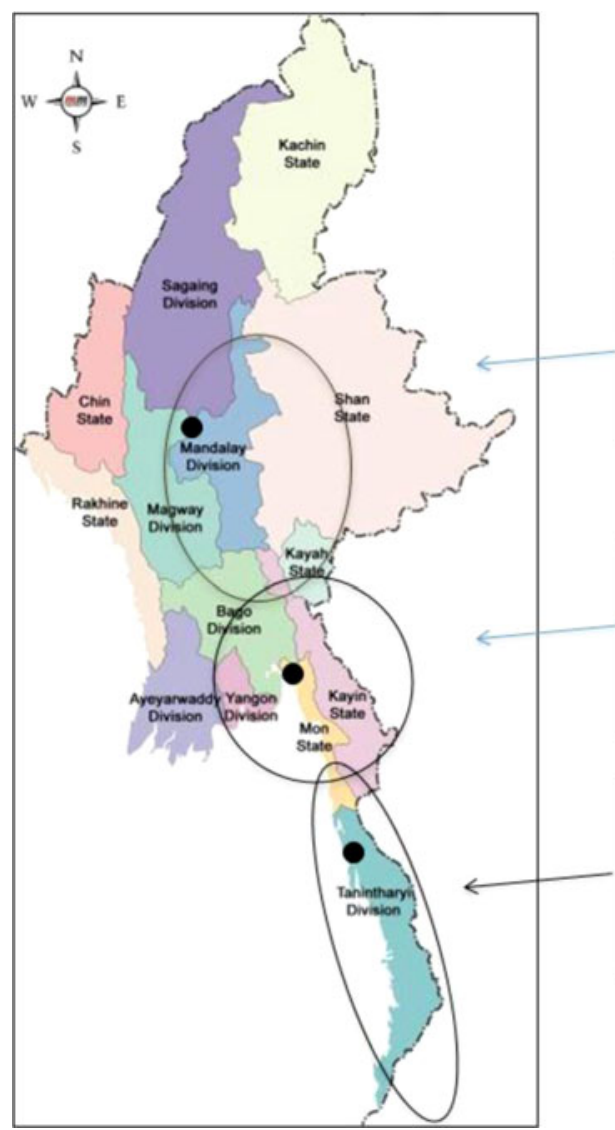

\begin{tabular}{l}
\hline UPPER MYANMAR \\
BAGAN \\
ARID PLAINS \\
$600-1200 \mathrm{~mm}$ rainfall \\
\hline
\end{tabular}

\section{LOWER MYANMAR \\ KYAIKKATHA \\ DELTA AND GULF \\ 4-5,000 $\mathrm{mm}$ rainfall}

SOUTHERN COASTAL ZONE

THAGARA

MARTIME \& OVERLAND

$5000 \mathrm{~mm}$ rainfall

Figure 1. Map of Myanmar showing the location of Bagan, Kyaikkatha and Thagara in relation to rainfall.

\footnotetext{
${ }^{1}$ Important locations are as follows: Bagan $\left(21^{\circ} 10^{\prime} 29^{\prime \prime} \mathrm{N}, 94^{\circ} 51^{\prime} 37^{\prime \prime} \mathrm{E}\right)$; Kyaikkatha $\left(17^{\circ} 21^{\prime} 46^{\prime \prime} \mathrm{N}\right.$, $\left.96^{\circ} 55^{\prime} 20^{\prime \prime} \mathrm{E}\right)$; Thagara $\left(14^{\circ} 10^{\prime} 24^{\prime \prime} \mathrm{N}, 98^{\circ} 10^{\prime} 05^{\prime \prime} \mathrm{E}\right)$; Halin $\left(22^{\circ} 28^{\prime} 12^{\prime \prime} \mathrm{N}, 95^{\circ} 49^{\prime} 07^{\prime \prime} \mathrm{E}\right)$; Beikthano $\left(22^{\circ} 00^{\prime} 14^{\prime \prime} \mathrm{N}, 95^{\circ} 22^{\prime} 46^{\prime \prime} \mathrm{E}\right)$; and Sri Ksetra $\left(18^{\circ} 47^{\prime} 54^{\prime \prime} \mathrm{N}, 95^{\circ} 17^{\prime} 24^{\prime \prime} \mathrm{E}\right)$.
} 
At Bagan (c. ninth to late thirteenth century AD), with the exception of its small (c. $140 \mathrm{ha}$ ) elite walled area, it is seasonal ponds and intermittent streams, rather than demarcating walls and moats, that identify the water management of the temple and village landscapes (c. 8000 ha) (Hudson 2004: 268). The Bagan plain was supplied from streams flowing down from the Turin Range across a broad plain that feed into a series of ponds, streams, canals, and the inner city moat before draining into the Ayeyarwady River (Cooler 1997: 22). These have been mentioned, but the primary context for the study of the urbanised landscape has been on the progressive expansion of the monuments and state power until it covered much of the territory of present-day Myanmar (Hudson 2004: 187). Where water has been noted, the focus has been on the absence of large-scale rice production, and the reliance on the rice fields of Kyaukse. These are generally dated to the eleventh century AD reign of Bagan King Anawrahta, codified during the reign of the Bagan King Narapatisithu (r. AD 1165-1211) and expanded thereafter to the Minbu and $\mathrm{Mu}$ River areas (Aung-Thwin 1990; Hudson 2004: 27, 45, 184; Moore et al. 2013; Yin Myo Thu 2011). While the twelfth century AD transformation in particular is well supported by epigraphy, remaining canals, and walled forts, it has left open the character of water management at Bagan in the preceding 900 years, from the traditional date for its settlement in AD 102 until Anawrahta and Narapatisithu's works.

Our case studies of Thagara, Kyaikkatha and Bagan purposely differ in size, ecological setting, and occupational sequence but are similar in the shared significance of small-scale water management in their rise and sustenance as urbanised sites. This significance is of course not unique to Myanmar, but our diverse examples show markedly less manmade change to the landscape than is seen elsewhere in mainland Southeast Asia. Myanmar water management has been little studied in contrast to the abundance of literature on the neighbouring mainland countries of Thailand and Cambodia. In Cambodia, the pre-Angkorean first millennium AD water management of circular sites such as Lovea recalls that of Myanmar, but the orthogonal regularity and clear central-periphery hierarchy that substantially modified the natural landscape of the cities of Angkor (ninth to thirteenth century AD) has little connection to the small scale adaptations seen at Bagan that we detail below (Acker 1988; Moore 1989). Even the less formal linear form of moated sites such as Angkor Borei (300 ha) and its links across the southern Cambodian delta to the lower Mekong Basin made a greater impact on the balance of manmade and natural elements than seen in Myanmar (Stark 2015: 77, 89). In addition, with the exception of recent explorations on Mt. Kulen, the bulk of the research done on the relationship of the monumental cities of Cambodia to the hydrology and landscape has focused on the extended urban area of Angkor.

In Thailand, the highly abstracted orthogonal forms of Angkor are absent, with two exceptions: the remnants of rectilinear Khmer tanks and temple 
enclosures on the Korat Plateau of North East Thailand spanning the seventh to thirteenth century and the late twelfth to thirteenth century Khmer centre at Sukhothai. The North East Thai Khmer settlements, perhaps due to the local ecology, never attained the size of urban areas around Angkor or the T'ai cities of Northern and Central Thailand. A recent study on 'water-based urbanisms' focused on Thailand's history of indigenous water management to call for greater attention to its heritage in contemporary urban planning (McGrath et al. 2015). The four ecological models defined in the study provide a geographical context: 1) at Chiang Mai, in the largest of the four 'intermountain basins' of Northern Thailand, a rectilinear city wall defines the central urban area, but its water supply and drainage come from a stream coming down from the adjacent mountain; 2) at Sukhothai, in which an earlier Khmer city was subsumed into the new T'ai city, hills on the west supplied the 'fan terrace' spread on the floodplain of the Yom River; 3) at Ayutthaya, the 'river confluence' site is at the 'choke point' where the northern rivers of the Ping, Wang, Yom and Nan converge; and 4) at Bangkok, the city sits within the young 'delta' lands on the Gulf of Thailand (McGrath et al. 2015: 50-51).

The existing literature on water management in Myanmar has concentrated on the emergence of Pyu irrigation, the control of water in Lower Myanmar sites such as Kyaikkatha and Thagara, and the reliance of Bagan on distant areas for rice. In Cambodia, the focus has been the extensive distribution and use of rectilinear water management for rice cultivation at Angkor with additional research on Angkor Borei in the south, and recently on the Kulen Massif. In Thailand, despite the presence of some Khmer settlements, the majority of water management has adapted to the particular ecology of each city to underline the flexibility of indigenous traditions of water management. We refer back to this geographical model in our description and assessment of indigenous traditions as illustrated by Thagara, Kyaikkatha, and Bagan.

\section{Comparison of Urban Areas}

\section{Thagara}

Thagara (105 ha) is an oval-shaped walled mound located on the floodplain of the north-south Dawei River. The site is recorded in local chronicles and early British accounts, but the first systematic mapping of its water management was by Aung Myint, a native of Dawei (Moore and Aung Myint 1991/1992). The Dawei River valley sits between tall ranges bordering the Andaman Sea on the west and Thailand on the east. The mountains do not shelter the valley from the rains coming in from the west, and the ranges also divert cold winds from the north to sweep with force down the valley to bring, in the past at least, a rise in malaria and rheumatism (Webb 1906: 2). With artefacts spanning $c$. ninth to seventeenth century AD, Thagara is the best documented of a series of ancient sites along the Dawei River 
valley benefitting from access to both maritime and overland trade routes (Moore and Than Swe 2006). The short Dawei River rises north of Thagara and flows due south to the current town of Dawei where it empties into an inlet and then the sea. Trade to the north was facilitated by the Dawei River and other north-south streams. The main river is not prone to flooding but the concentration of the $5842 \mathrm{~mm}$ of rainfall between June to mid-October often causes inundation of villages and fields (Fig. 2).

Thagara and other sites are set back from river banks close to the hills on the west. This is an advantage for the provision of drinking water as thick deposits of clay along the river banks make wells almost impossible. Near the foot of the hills,

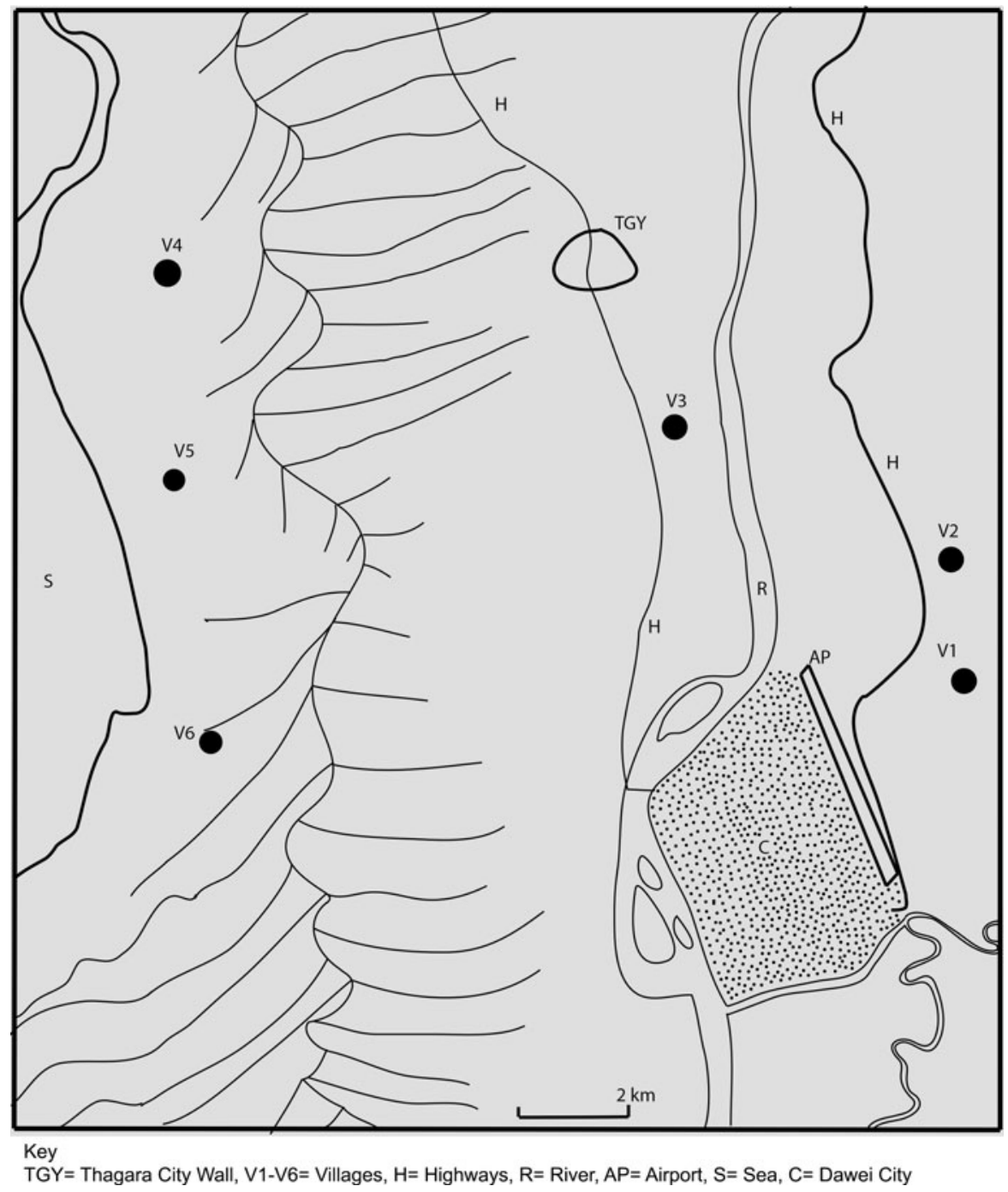

Figure 2. Overview Map of Thagara showing the city wall and surrounding features noted in the Key. (Map by Pyiet Phyo Kyaw) 
however, year round wells provide a good water supply (Webb 1906: 2). The water for the rice fields around Thagara comes from Byin-tin-taung Hill (52 msl) half a kilometre to the west of the site. Water from the hill flows through the Hsin-Panit-chaung or stream to the north, a fresh-water alternative to the salt-laden water of the Dawei River (Naing Soe, pers.comm. 03.2016). Roads from here provide access over the hills to the coast. As these details suggest, Thagara is well supplied with water with the principal water management need being the prevention of flooding within the village, the channelling of water to the fields, and its conservation during the dry months. These necessities are managed through a series of walls and moats constructed around the village mound (Plate 1).

The Thagara mound has only a slight incline, descending from an elevation of 10 metres on the west just north of the entry to the Anauk-kyaung (western monastery) to 6 metres east of the eastern jetty and on the south where the Padat Chaung stream enters. Water is channelled along the southern to the eastern moat (11 metres) around the jetty. Rice is cultivated in the fields surrounding the site, with the remains of Daung Thein, a small ordination hall 200 metres northeast of the outer wall on the north suggesting that this has long been the case. Rice was for the most part sold locally, although early twentieth century records note that the export from the villages along the Dawei River was not primarily sent to Rangoon, but south to the Straits Settlements on the Malay peninsula (Webb 1906: 9).

Houses fill much of Thagara although a quarter near the ancient jetty is used for garden cropping. This quarter is also a source of polished ancient beads turned up by farmers during ploughing. The Shin Zalun Stupa $(22 \mathrm{msl})$ on the

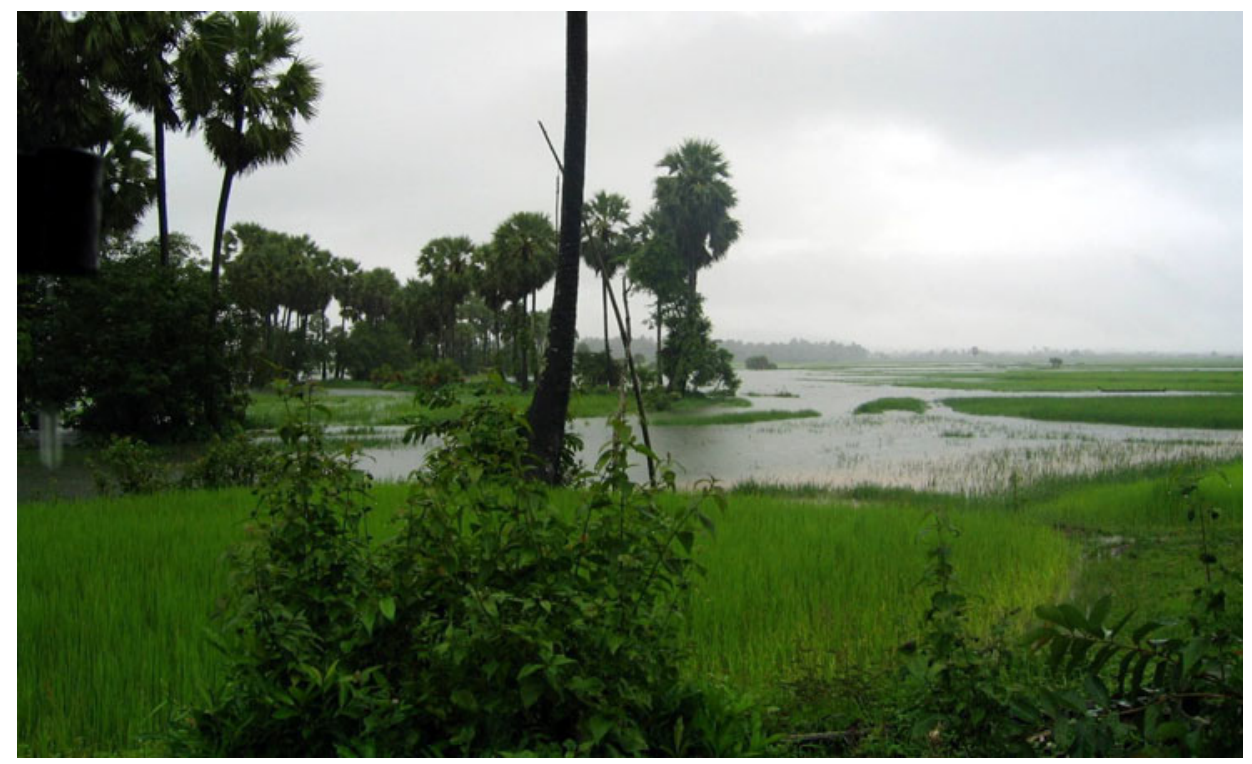

Plate 1. The southern side of Thagara seen during the rainy season. (Photograph E. Moore, 2004) 
northeast marks the highest point of the site, sloping to the southwest wall (7 $\mathrm{msl})$. Rainfall is variable from year to year with early British records of rainfall recording $7245 \mathrm{~mm}$ in 1904, more than $1000 \mathrm{~mm}$ greater than the previous high recorded in 1896. Irrigation is only used in the areas of mayin or flooded rice where small bunds can be placed across streams to ensure a supply that is slowly fed into the fields as the crop ripens (Webb 1906: 2, 7).

One to four walls and moats surround the perimeter of the Thagara mound with an inner wall enclosing c. 52 hectares (Plate 2). Erosion over time has destroyed a number of the sites original features. On the southeast for example, a ground check by the Department of Archaeology documented a curved wall, now almost gone, that was part of the ancient water management system (Thura Bo, pers. comm. 2014). Thagara protrudes on the east where the remains of a former jetty (c. 200 metres long) link to a stream, the Padat Chaung. The outer southeast wall runs from the jetty to the southern gate, with the road stretching southwards towards the village of Launglon. Some suggest that this road is a modern access way, but the connection of the southern wall on to the jetty is likely to have provided an area to disembark goods transported down the Dawei River. From there the goods could be sent south to the egress of the river, or west across the mountains to the coast. The presence of a southern gate is reinforced by the higher remnant third and fourth outer wall on this side (Zaw Win 2013: 5).

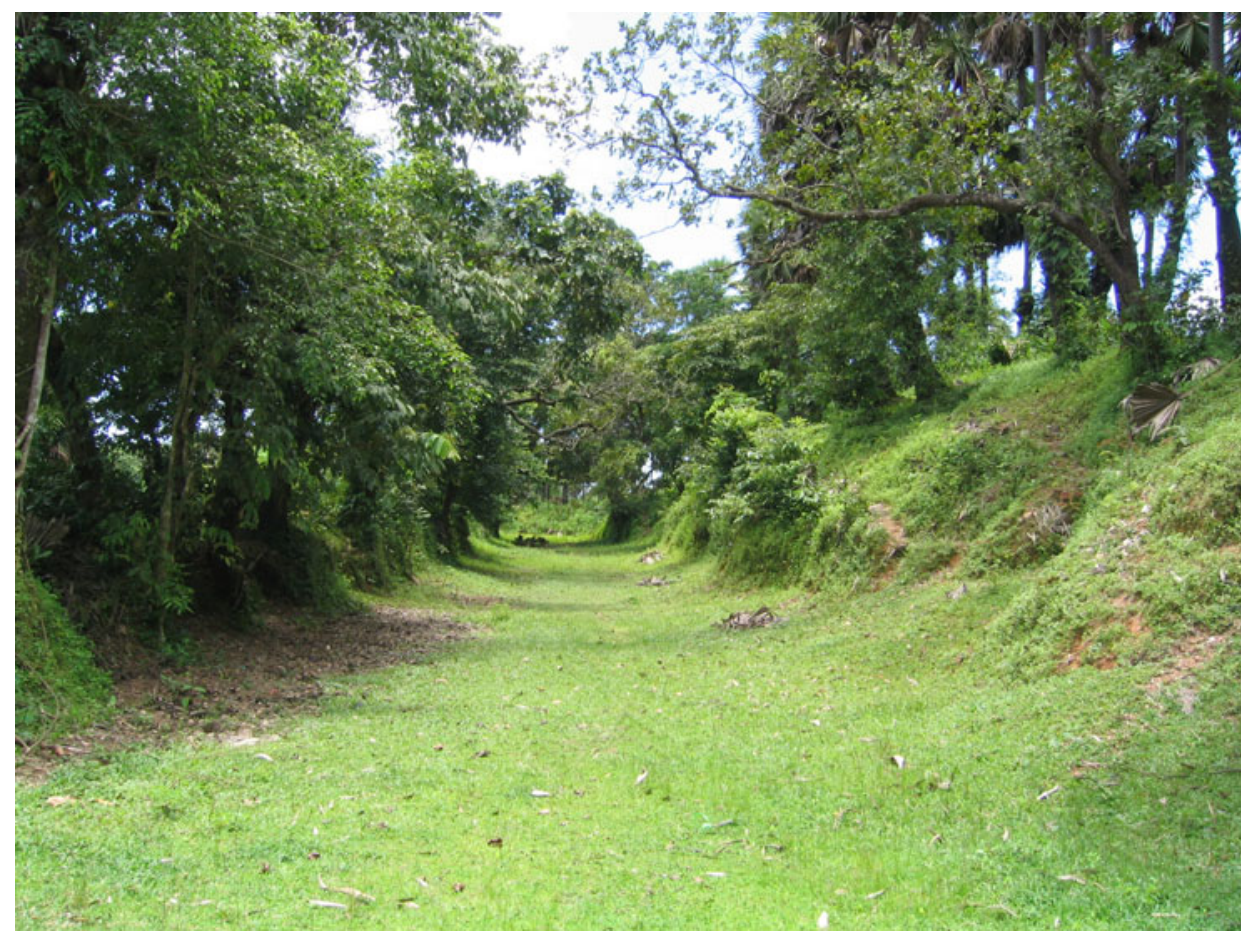

Plate 2. One of the moats and ramparts on the northeast side of Thagara. (Photograph E. Moore, 2004) 


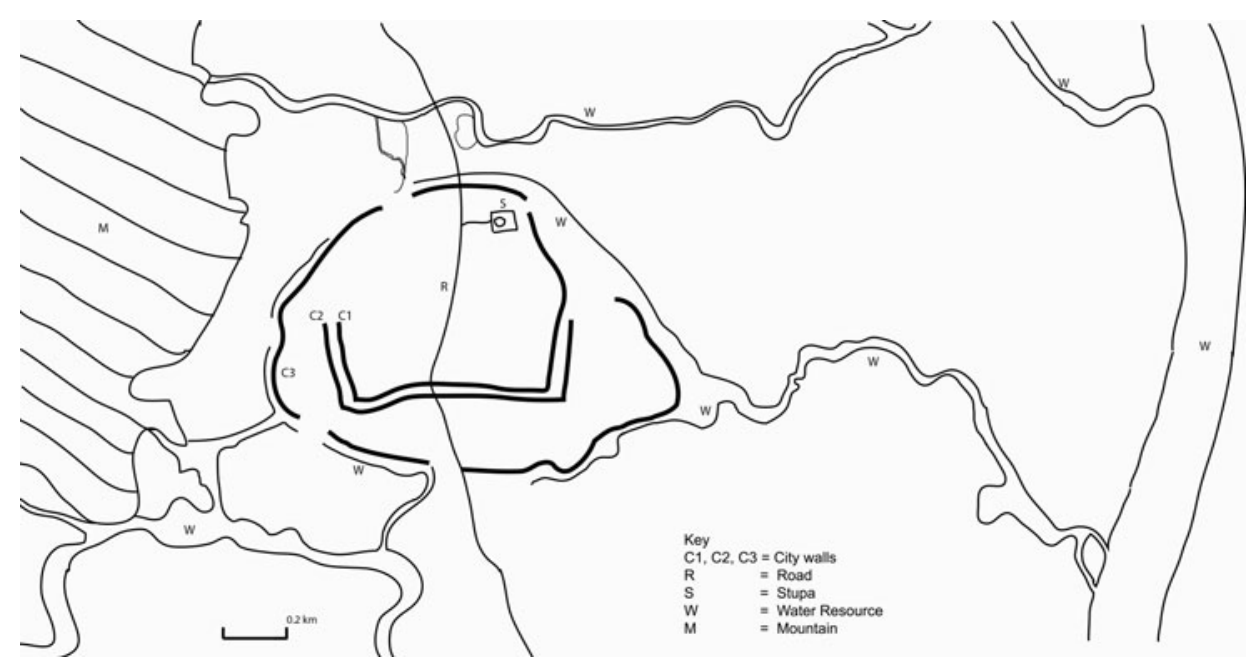

Figure 3. Detailed map of Thagara showing its location between the mountains and the river, with features identified on the Key. (Map by Pyiet Phyo Kyaw).

The walls are not continuous, there is a remnant moat on the north, and, today, a small lake adjacent to an ancient brick structure (SGR-1). This was excavated by the Department of Archaeology in 1999-2000 but without the time to section the moat (Ngwe Ngwe Soe 2000). With the exception of the eroded west side, the outer walls are higher and moats wider than the inner ones. The widest moats are on the east between the third and fourth city wall (90 metres) and on the south between the third and fourth enclosing wall (183 metres) where water coming from the west would have drained. In addition, with the exception of the west side, the outer walls are higher and moats wider than the inner ones, suggesting that each wall may have been built over a short period of time, perhaps in response to flooding, or a successive increase as cultivation expanded.

In the dry season, water ponded in the moats, such as seen near SGR-1 outside the north wall. In the rainy season, they effectively channelled water coming down from the west around the site and thus protected the inner walled portion where the village is located today. Water management was essential, even in recent years the village mound was inaccessible due to flooding in the surrounding fields. The manmade walls and moats simply and effectively channelled water, with additional walls built in times of need. The traditional wooden architecture of Thagara village today is beginning to be replaced with brick houses, markers of prosperity (Fig. 3).

\section{Kyaikkatha}

Kyaikkatha (269 ha.), like Thagara, is a raised site surrounded by a series of walls and moats. Aung Myint, who also pioneered work on the water management at Thagara, first identified Kyaikkatha from aerial photographs in 1976 and was able 
to ground verify it in 1981 (Aung Myint 1998: 104). The moat is typical of many ancient walled sites in the Mon State with its abundant use of laterite (gawun). There are three major differences, however: 1) Kyaikkatha is not located along an intermountain river valley like Thagara, but on estuary land at the mouth of the Sittaung River where it empties into the Gulf of Muttama (Martaban); 2) Unlike Thagara, where water inside the walled perimeter is primarily sourced from wells, the water management of Kyaikktha includes seasonal ponds and channels within the walled area; 3) Its elevation varies from 8-50 metres, giving a considerably greater slope to assist water management (Plate 3).

There are in addition two main streams, Kha Lon and Ma-law-chaung, that flank the ancient city before connecting to the mouth of the Sittaung River on the west. Laterite quarries and tunnels northeast of the site continue in active use today with groundnut and betel cultivation where the elevation increases rapidly to $c .50 \mathrm{~m}$. Just outside the northeast wall, the valley of the Kha Lon stream possibly connected to the northeast corner, supporting drainage to the lower sections acting as water basins to reduce inundation levels (Pelzer 1968: 275). As at Thagara, ramparts may have been constructed rapidly in sections in response to flood, so that while the mound appears enclosed by continuous walls, the breaks in these may not be due to deterioration over time.

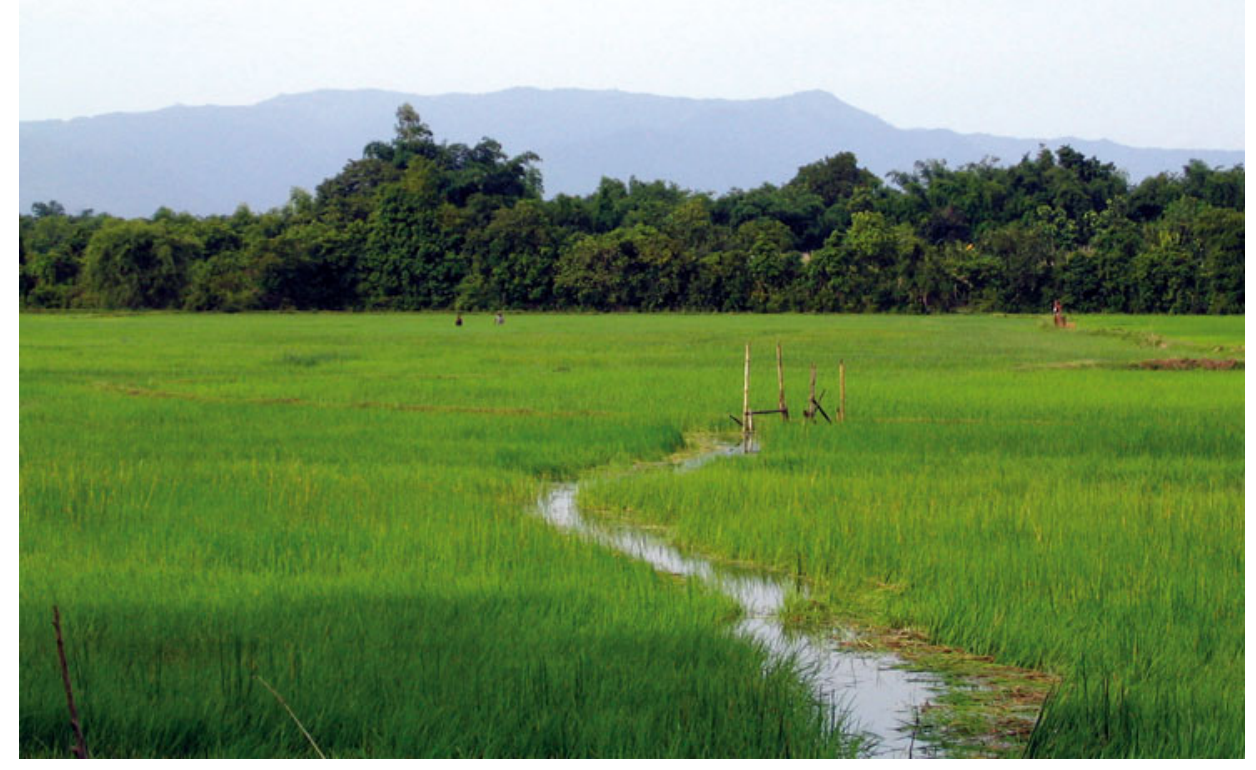

Plate 3. Photograph of the eastern part of the enclosed area of Kyaikkatha, looking east. (Photograph by E. Moore, 2006) 
The Kyaikkatha walls were strategically built at points of water stress using a combination of earth, laterite blocks, and bricks. The two outer walls range from 8-21 $\mathrm{m}$ in width, with the flanking moats $4-17 \mathrm{~m}$ wide. The eastern third of the site is broader and higher $(23 \mathrm{msl})$, enclosing a partially man-made lake, In-kalain (c. $250 \mathrm{~m}$ wide and $1000 \mathrm{~m}$ long, $13 \mathrm{msl}$ ). This area is flanked by a northeast hillock and then slopes toward the south and southwest through the Ma-lawchaung stream located southeast of the In-kalain reservoir. In that area, there is a series of small reservoirs going from north to south: In Nhamagyi (Elder sister Lake), In Nhamalay (Younger Sister Lake), Seinkalei In (Mon Village), Kalapchap In (Mon Hamlet), Dawbalein In (Mon name), In Lya Shay (Elongated Lake), Aingma (Mother Lake), and Shwebochaung (place where gold pieces could be found). From Shwebochaung, there is a man-made canal $(c .1000 \mathrm{~m})$ connecting to the east of the Kyaikkatha In-Kalain reservoir that crosses through the Hpaya-tataung (one thousand pagoda complex). This man-made canal connecting with many reservoirs and lakes is probably been the most important part of the Kyaikkatha water management system. Absolute dating and excavation of the canal has yet to be carried out but its role in the site's sustenance suggests contemporaneity with the first millennium AD recorded in the Department of Archaeology's earlier excavations within the walled area.

Part of the eastern wall of Kyaikkatha contains a series of laterite cells $(\mathrm{Mu}-$ hsoe-ma-gu) associated in local legend with a Khmer princess pining after the local prince who traditionally founded the site (Tin Gyi 1931: 28). Other tunnels are found c. $3.2 \mathrm{~km}$ north of Kyaikkatha at Natkyizeik, east at Hpayatataung (noted above) and farther south near Thaton at the site of Mayangon. Trenches such as these may well have provided cover for attacking troops and during longer sieges. After the British victory at Yangon in 1824 AD at least $10 \mathrm{~km}$ of trenches were documented reaching from Kemmedine to Poojadown (Charney 2004: 98). While not directly connected to water management, the tunnels are a key part of the wider exploitation of laterite at Kyaikkatha and other sites in the region.

At the centre of the walled site is Kyaikkanon Hill (50 msl, $750 \mathrm{~m}$ across) with a laterite stupa on the summit. The hill is surrounded by six to seven steep-sided walls separated by moats, each 10-15 $\mathrm{m}$ wide that mirror the contours of the natural hill $(50 \mathrm{msl})$. While these are part of the site's water management, their form and placement suggest a cosmological significance not seen in the outer walls and moats of the site (Plate 4).

Kyaikkatha sits between two walled sites that may have served as satellites or sentinels. To the north, it is flanked by the walled site of Sittaung (72 ha, Kyaikkalun Pon Hpaya), one of the 32 myo (towns) of the sixteenth century AD kingdom of Hanthawaddy. On the southeast is Kaw Htin (16 ha.), protecting the road to Kyaikto. (San Win 1986, 2002, 2005) (Fig. 4). While both Sittaung and Kaw Htin are much smaller in terms of the area enclosed by walls and 


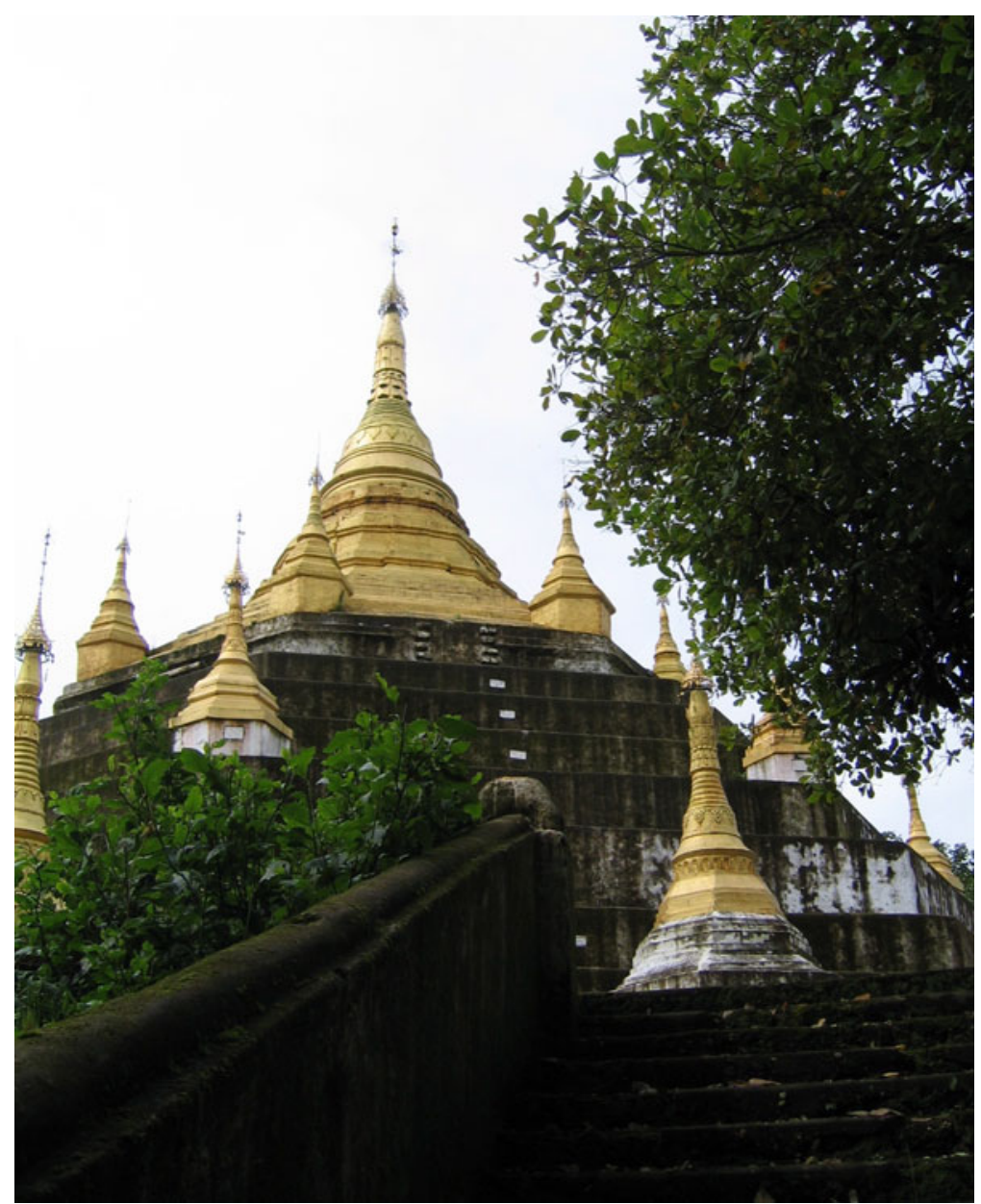

Plate 4. Kyaikkanon Hill near the centre of Kyaikkatha. (Photograph by E. Moore, 2006)

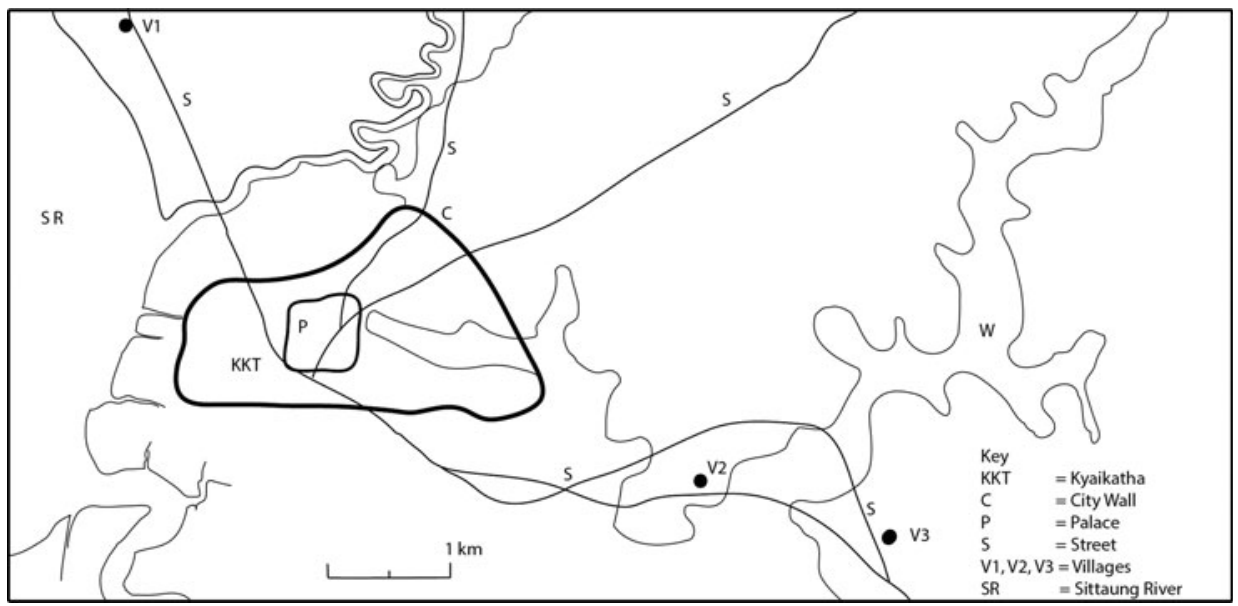

Figure 4. Map of Kyaikkatha showing its proximity to the Sittaung River with surrounding features identified in the Key. (Map by Pyiet Phyo Kyaw) 
moats, both have multiple ramparts and moats. This proximity underlines the primary function of the features - whatever defensive purposes they also served - to control and conserve water in a manner that recalls the distribution of moated sites in Central Thailand (Mudar 1999).

The location and water management strategy of Kyaikkatha responded, like Thagara, to high rainfall concentrated within a few months of the year. However, as detailed above, the estuary setting, exploitation of laterite, and the use of the naturally occurring slope of the land are different. The water management adeptly linked internal ponds, canals, and moats to natural streams and seasonal ponds. This breaching of inner and outer parts of the site, and the varied land use within the walls are more akin to our final example of Bagan with its "porous mix of urban and agricultural patches" (McGrath et al. 2015: 52).

\section{Bagan}

Bagan is not defined by an outer wall, as is the case at Thagara and Kyaikkatha. There is a small walled area, noted in the introduction, but the space understood as 'Bagan' also encompasses the villages and the thousands of monumental brick spread over 8000 ha across the broad plain. Pagan residents were never far from rural zones, and numerous spaces within the settlement were used for agricultural production (Cowgill 2004: 539). Many authors conclude that, given Pagan's location along the massive Ayeyarwady River, a fourth wall once existed that has now been eroded, however, other scholars contest this idea (Thin Gyi 1966: 179). In the mid-1990's as part of the city's reconstruction, the broad (100-150 feet. 30.5-46 meter) moat around the inner city wall (68 meter msl) was revived, but to fill this moat water had to be mechanically pumped up from the Ayeyarwady River $(50 \mathrm{msl})$ suggesting that the river was not the historical source for moat water.

This reinforces our view, that the water management in Bagan was defined by intricate but small-scale diversions, exploitation of ponds and lakes, and strategic siting of temples in relation to water. There have been few studies of Bagan that focus on water and use the site's aridity or riverside location as a defining element as we do here (Cooler 1997; Lubeigt 1998). Below we discuss three selected examples of water management from many found at Bagan. We've selected the following: the storage tanks on the Turin (Tuyin) Range located $12.9 \mathrm{~km}$ southeast of Bagan; water diversion and storage around the Sulamani Temple; and, finally the present day use of the Ayeyarwady River.

\section{Turin Range Water Storage}

The Turin Range (c. $300 \mathrm{msl}$ ) with the Turin (256 msl) and Thetso (4123 msl) peaks is geologically related to the extinct volcano of Mt. Popa (c. $1500 \mathrm{msl}$ ) located $48 \mathrm{~km}$ to the southeast (Phyo Ngwe Yee 2011: 9). At the western foot of Turin and Thetso, the ancient reservoir of Mya Kan or 'lake' has been 
reconstructed as Mya Dam. The stupa on Turin Mountain is one of four Early Bagan stupas associated with King Anawrattha that traditionally mark out the sacred landscape of the city. The others are the Shwezigon at Nyaung Oo, Lawkananda at Thiripyitsaya, and Tant Kyit Taung Stupa of Tant Kyit range on the opposite bank of the Ayeyarwady. On the top of Thetso Mountain there are three lakes quarried from natural sandstone that may have been used for water storage by forest-dwelling monks (Ni Tut 2013: 166). The largest, known locally as Nat Yekan (or Spirit Lake) measures $26 \mathrm{~m}$ x $14 \mathrm{~m}$ x $7 \mathrm{~m}$, with a capacity of 2660 cubic meters (Ni Tut 2013:161). The interior walls of the lake are faced with sandstone bricks in various shapes and bear carvings of a crocodile, a labyrinth, a serpent, two hamsa birds, a goose, a heron, a tortoise, and two fish. These retained the eastern and northern wall, possibly to support the lake against water erosion from the lake's upper portion.

Some villagers regard Nat Yekan as the predecessor of the Mya Dam at the western foot of Turin Range (Ni Tut 2013: 161). Inscriptions refer to it as a vital water-storage for Arañ or 'forest-dwelling monks' (Maung, 1958: 44). Its construction may have been around the same time as the Sulamani (AD 1183) water drainage infrastructure was created (described below) and the Dhammarajaka (AD 1196) pentagonal stupa erected (Ni Tut 2013: 162). A Mon language inscription indicates that the Turin stupa and Mya Kan pentagon are related to the dedication of King Kyansittha (Chit Thein 1965: 47-9; Than Tun, ND: 35-6). A lake is also mentioned in the Thetso Taung (Mountain) inscription of AD 1211, a date that would associate it with King Narapatisithu (AD 1165-1211) or Nantaungmya (AD 1211-1234) (E Maung 1958: 46; Ni Tut 2013:162). A further record of the sandstone lake may be the Paw Daw Mu Phaya inscription located on Thetso Mountain. Although this inscription does not include an exact date, it has been suggested that it might have been donated in $1196 \mathrm{CE}$ (Ni Tut 2013: 162). The list of donation records one monastery; eight banyan trees; a preaching hall Dhammasa; one lake being dug and those two sons entered the monkhood. (E Maung 1958: 1; Ni Tut 2013: 162).

As can be seen in the multiple inscriptions referring to tanks, water storage during the dry season from December to May was crucial. Storage tanks and epigraphy and the detailed inscriptions we cite above have not been documented at either Thagara or Kyaikkatha. This is also the case in our next feature, Sulamani Temple located southwest of Turin and connected to the range via a series of intermittent lakes and ponds.

\section{Sulamani Water Management (Twelfth to Thirteenth Century AD)}

The Sulamani Temple (temple no.748) as recorded in the Sulamani Inscriptions of King Narapatisithu was built in AD 1183 (Yin Myo Thu 2013: 12-4). It is not only in the middle of the distribution of temples across the Bagan plain but midway between two important sources of water. According to the inscription, the temple was built over landfill on a gorge suggesting that the foundation 
may have earlier been a water reservoir. This is supported by the presence of water inlets at the foot of the massive enclosure walls that allow water to drain underneath. In addition, the temple is surrounded by a number of large reservoirs: Nyun Lat Ta Phat Kan, Pho Thu Daw Kan, Ta Wet Kan, Ma Gyi Kan, Htein Kan and the Tha Beik Mauk and Sulamani drainages (Fig. 5). Details of two of these give an idea of the way in which they maximised the slight slope and natural water features:

- The Nyun Lat Ta Phat Kan, which roughly translates as 'swamp one hand' referring to the retaining dam on the lower slope side, is indicative of the careful placement of water features to utilise the land's natural slope.

- Pho Thu Daw (or 'white-robed acolyte'), like Nyun Lat Ta Phat (above), was made by damming up the open end of a ravine. In this way water from Ta Wet Lake was stored in the Pho Thu Daw Lake.

This careful siting of water management features at points of stress is well illustrated by the water management features around Sulamani Temple. We describe these below, moving from the east, to the north, and then western sides of the temple.

On the northeast part of the eastern enclosure wall, a water inlet underneath the wall channelled water from the eastern water storage by Tha Beik Mauk Temple east of Sulamani and the Nyun Lat Ta Phat Kan reservoir still further east. In front of this temple is a floodgate made of sandstone blocks from Nyun Lat Ta Phat Kan. The water going over the floodgate flows through the southern enclosure wall of Tha Beik Mauk Temple and enters into the eastern

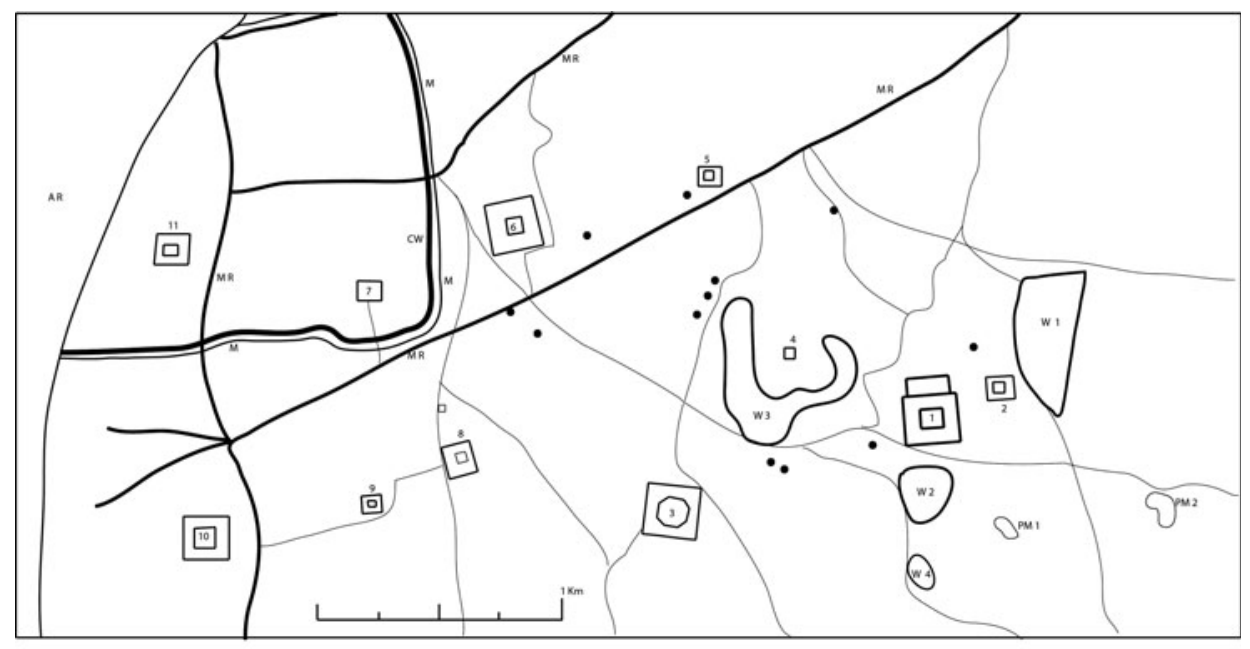

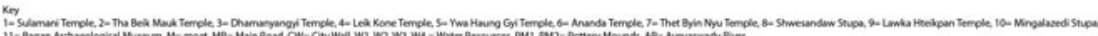

Figure 5. Map Overview of the Sulamani area with relevant features noted in the Key. (Map by Pyiet Phyo Kyaw) 
water storage of Sulamani Temple. The water collected in this pond flows into the Sulamani compound through the water inlet underneath the enclosure wall.

On the north side of Sulamani, there is a modern monastery called Sulamani Monastery that overlies an ancient monastery (Pichard 1994, no. 745). There is another water inlet to the northern monastery complex located in this place. From the small pond in the northern part outside the eastern wall of Sulamani Temple, the drainage channel was connected to the Sulamani pond in the ancient monastery now inside the modern one. This channel was constructed with a radiating arch brick bonding, an advanced system still used today. The water inlet hole is a zig-zag layering of bricks vertically inside, the largest water inlet of Sulamani Temple (Fig. 6).

Pichard describes monastery no. 745 as a pond and connecting channel made of flat-bricks but does not described the system of water management in detail. The connecting channel noted in the Inventory is only one part of the Sulamani water management system. A similar system of drainage associated with eleventh century AD Bagan was discovered in 2003 during excavations of the Bagan palace site. At that time drainage points constructed with vertical brickwork were unearthed on the west and northwest of the palace site (Department of Archaeology 2013; Phyo Ngwe Yee 2011: 21). Sulamani's drainage may have continued in this way to connect multiple reservoirs, each one to the next. Pichard gives the monastery complex an estimated date of as thirteenth or fourteenth century,

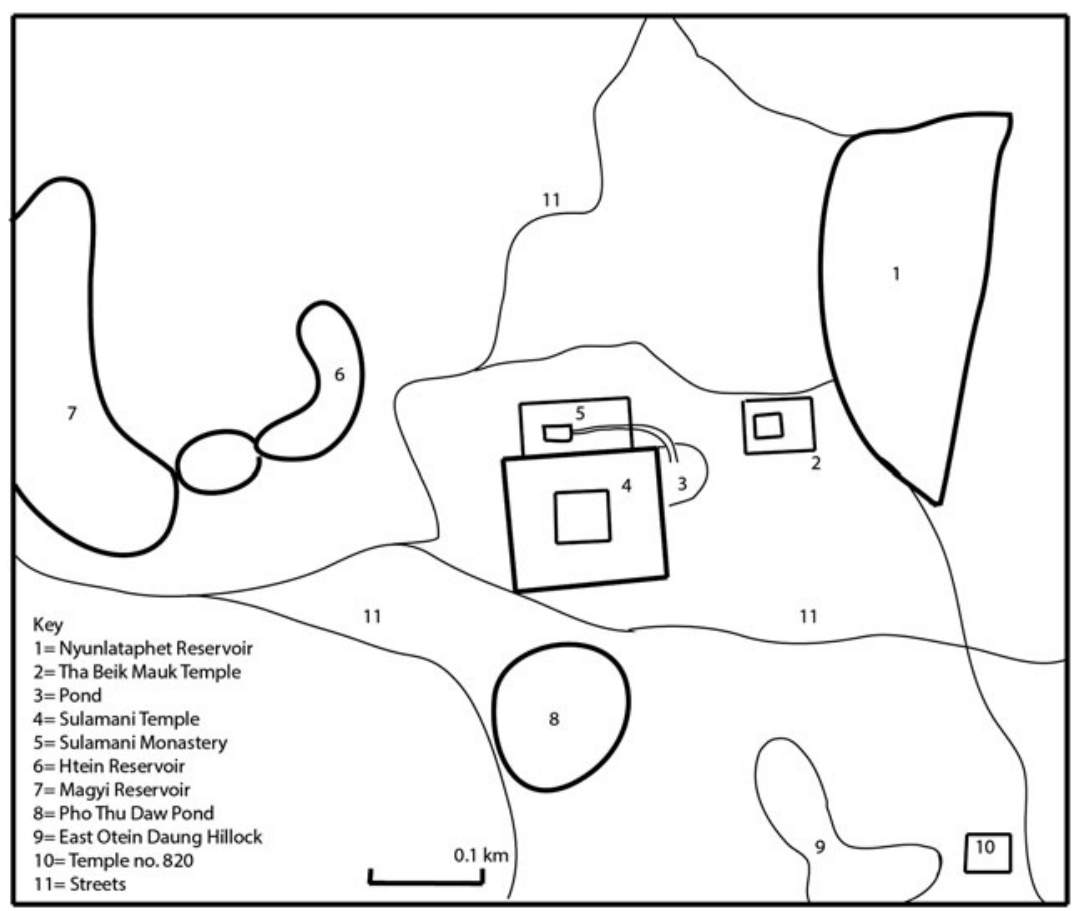

Figure 6. Map detail of the water flow around the Sulamani temple with relevant features noted in the Key. (Map by Pyiet Phyo Kyaw) 
suggesting that the complex was attached after the temple construction in this later period (Pierre Pichard 1994: 293).

In northern enclosure wall, there is one water outlet underneath the wall. The water inside the Sulamani compound can flow through this outlet to reach the northern monastery complex. This water outlet, no larger than the one underneath the eastern wall, was constructed with a straight archway brick bonding system. It slopes toward the north and west of Sulamani Temple. Water was collected in the small pond outside the eastern enclosure wall of Sulamani Temple with floodwater reaching inside the temple compound and then able to continue to the northern monastery complex through the northern water outlet. The northern outlet was joined with the long connecting channel to reach the water inlet of Sulamani Pond now located in the modern monastery (Plate 5).

In western enclosure wall, there are four water outlets underneath the wall, two on the northern part of western wall and two on the southern part. The Pagoda Trustees today use these water outlets to connect plumbing pipes. These four outlets can be observed today with the western face of Sulamani Temple is as the main entranceway. The western outlets are not as large as the other outlets and were constructed with straight archways. When the rainfall is heavy, Sulamani compound is full with water and the drainage system can easily be seen.

Northwest of Sulamani Temple, there is a distinctive square-shaped water reservoir enclosing an island traditionally, called an Udakukkhepa or monastic water

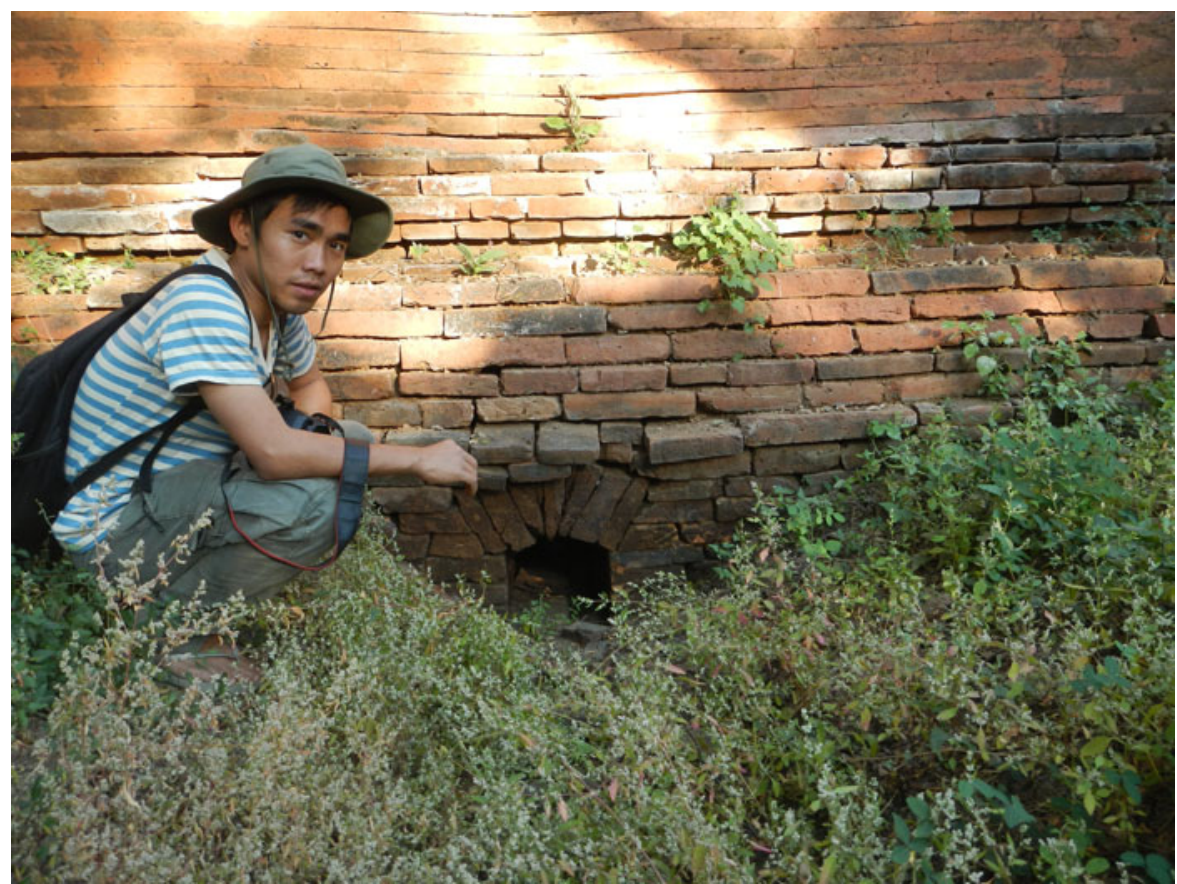

Plate 5. Water outlet at the base of the northeast part of the eastern enclosure wall. (Photo E. Moore, 2014) 
sima (Kieffer-Pulz 1997: 142). Field survey showed that this reservoir could be divided into two portions: Ma Gyi Kan on the east, and Htein Kan on the west. On the enclosed central island, there is a two-story temple named Leik Kone (Tortoise Shell Temple). Around the environs of this temple, the land elevation is lower than the eastern Sulamani area. Due to this slope, flood water is collected in the sima reservoir. From there water goes through the Ananda Temple area, and then to the inside of the southeast corner of the Bagan inner city moat. In the rainy season, water goes directly from the Nyun Lat Ta Phat Kan through the compound of Tha Beik Mauk and Sulamani temples, and then to the city moat.

The Sulamani area is $c .600$ metres west of the eleventh century temple No.820 located between East and West Otein Taung, which contain two large pottery mounds. It has been suggested that officials in charge of a postulated ninth to fourteenth century AD village located near the two mounds may have sponsored the temple (Hudson 2004: 207-219; Hudson et al. 2001). While not directly connected to Otein Taung, the water management features around Sulamani are part of the same sequence of intermittent ponds linking the Sulamani area to the Turin Range on the southwest and the walled inner city of Old Bagan on the northwest.

In summary, Sulamani water inlets and outlets are a complex and systematic arrangement of water storage and drainage system dependent on the Nyun Lat Ta Phat Kan water reservoir in the northeast sector of Sulamani Temple. This reservoir maintains the floodwater flowing from the hills connected to the Turin Range on the southeast and the Minanthu Reservoir ( $80 \mathrm{~m}$ x $80 \mathrm{~m}$ x $6 \mathrm{~m}$ ) lying to the north east of Nyaung Oo still in use today. Due to limitations of space, we do not detail the Minnanthu system here, except to note in passing that numerous local customs are linked to the water features. For example, it is popularly said that Minanthu villagers believe that water would be putrid if the water of the Minanthu Lake mingled with that of Tha Htay Kan Lake located east of Dhammarajaka Stupa.

\section{The Inner City Wall Moat}

As noted, water moves from the sima reservoir to the northwest of Sulamani towards the Bagan inner city wall. This wall was traditionally built in the ninth century AD with excavated evidence of thirteenth century King Tayokepyay (also known as King Narathiha Pati) rebuilding it with bricks from hundreds of temples so that it even incorporates finger-marked bricks associated with the early period of Bagan (Than Tun 1996: 192-3). When heavy rain falls, the southeast portion (1070 m long) of the inner city moat is filled with water; the surface of this water serves to mirror both the Ananda and Thatbyinnyu temples.

As shown in our earlier description of the movement of water from the northeast of Sulmani, through the temple and additional water management features further west, the water resources of the plain connect to this moat, not to the river as is sometimes thought. This is further supported by efforts in the 1990s to fill the moat from the river. The inner city moat on the southeast side was excavated and conserved 


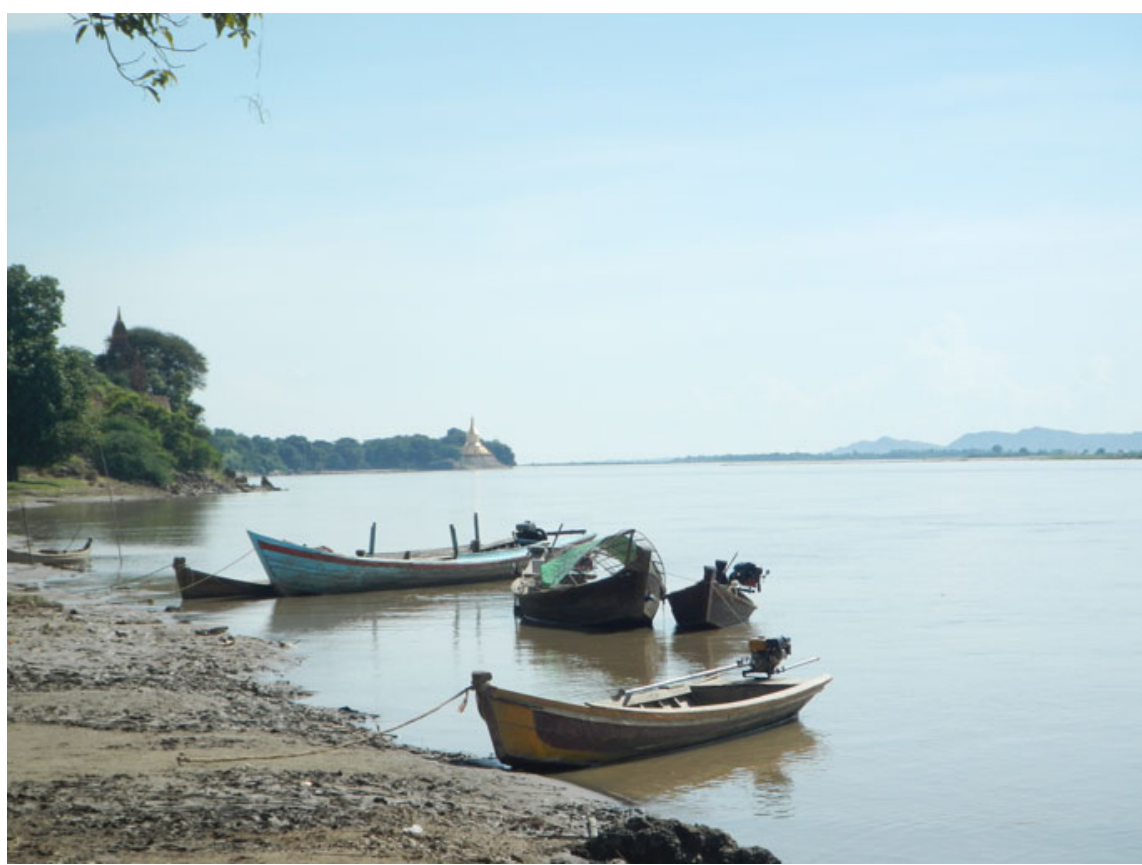

Plate 6. Small craft along the shore of the Ayeyarwady River. (Photo E. Moore, 2015)

between 1989 and 1995 and again in 1997, 1998, and 1999 (Phyo Ngwe Yee 2011: 11-4). The excavated bed of the moat was 19 meters wide, and 36 meters wide at the top. The newly excavated moat was mechanically filled with water from the Ayeyarwady although the moat was about 15 meters higher than the riverbank, a greater drop than near the Buphaya Stupa to the south. Even when the Ayeyarwady River was flooding, the river water level could not reach the deepest portion of the moat (Plate 6). Thus, in the heyday of Bagan, the water level of the Ayeyarwady River likely reached only to the mouth of the moat at the very most (Phyo Ngwe Yee 2011: 15-6). In addition, as with many features of the overall Bagan system, the moat stored water in the rainy season. Drainage for rainwater can also be seen between the northern causeway of Ananda Temple and Taingchut Temple and from the southern causeway of Ananda Temple on the western part.

In summary, Bagan is located in a semi-desert rain shadow area where the soil easily absorbs water. Muddy areas are better for water storage when heavy rains fall, thus, traditionally the floor of water storage area was plastered with cow dung for better retention of water (Than Tun 1985: 20). This system was crucial in all eras of Bagan and can be seen from the Kyaukku Uhmin cave temple, to the Shwezigon Stupa, the Ananda Temple, and the eleventh century buildings in Myinkapa area (Kan Hla 1977: 19). By the middle of the twelfth century, temples were being built some four to five kilometres inland from the riverbank, but from the Shwezigon south to Thiripyitsaya Village, and at villages such as Wet Kyi Inn, Taung Bi and Myinkapa, the complex water management system was complemented by water usage opportunities offered by the bank of the river which we discuss in the next section. 


\section{Jetties along the Ayeyarwady River bank}

The Ayeyarwady River contributes an additional element to understanding the overall water management system of Bagan. During the dry months, even the mighty Ayeyarwady River is at times so banked up with sandy shoals that it cannot be easily navigated, and in places can even be crossed by bullock carts or on foot. The founding of Bagan relied on the flow of the Ayeyarwady River, as evidenced in the numerous eleventh century Bagan monuments built along the riverbank. For example, at Nyaung Oo in the densely populated northernmost part of Bagan, Kyaukku Uhmin Cave Temple was only accessible by the river from the Kyaukku Uhmin Jetty, located along one of many high cliffs found in the Nyaung Oo area. At Nyaung Oo Kan Par Cliff, for example, there are many jetties to disembark from boats. Today, the Tharawadi Jetty of Nyaung Oo Town is the largest place for the ship and cargo boats to dock.

The height of the riverbank drops as one moves south along the river. At Myinkapa for example, there is a mango woodland and a bathing beach used by villagers. Each point along the shore had a signal pagoda used for navigation: at Nyaung Oo there is the Shwezigon; at Wet Kyi Inn creek mouth is the Wet Kyi Inn Temple; at Taung Bi the signal pagoda is the Bu Phara Stupa, the Kantaw Palin Temple, and the Mingalazedi Stupa; for Myinkapa there is the Soe Min Gyi Stupa and mango wood; and finally, for Thiripyitsa there is the Lawka Nandar Stupa.

The Ayeyarwady was not managed, but as we can see from the numerous jetties and temples, the river was a vital part of the city. On the other hand, the intermittent streams flowing from the southeast to the northwest were, in contrast, carefully channelled to protect temples and provide water to the monasteries and villages. On the Turin Range, water was stored and used by monasteries along the ridge. Water management is best understood through this combination of three strategies. The primary goal of this system was not irrigation, which is the common focus for studies of water management, yet we can say that without the water management strategies developed in the dry Bagan ecological zone, the city would very likely neither risen, nor prospered.

\section{Discussion ANd Conclusion}

The ecology of Thagara, Kyaikkatha and Bagan each presented unique challenges but in each case, water management enabled survival. The three sites are similar in making little attempt to exploit the adjacent river for water, using major conduits solely for transportation and trade. Kyaikkatha did not draw from the $c .1200 \mathrm{~m}$ wide mouth of the Sittaung River on its western flank. At Thagara, two kilometres west of the 250 m wide Dawei River, the river was used for transportation, but water management relied on smaller and closer streams such as the Padat Chaung to the south and the Hsin-panit to the north. As the Padat Chaung draws from the brackish Dawei River, the Hsin-panit coming down from the Byin-htin-taung on the west, 
along with several wells, provides fresh water (Naing Soe, pers.comm. 03.2016). Thagara and Kyaikkatha with multiple ramparts and moats delineating a distinct elevated nuclear habitation site are worlds away from the immense spread of monuments seen as constituting the political centre of Bagan. Additionally, unlike Bagan where the principal rice cultivation was in areas far distant from the city, at Thagara and Kyaikkatha rice was grown locally within and around the area defined by the walls and moats. Our focus in this article has not been the diversion of water at these sites for the purposes of irrigation, but rather its role in defining what scholars today perceive as an urban area. This urban landscape was made through peoples' "understanding and engagement with the world around them" (Bender 2002: S103). Indigenous strategies for water use were largely practical and, we contend, less aimed at proclaiming urbanism or a centre-periphery hierarchy. Rather they represent a constant accepting of and coping with the changes of the monsoonal regime. The features we have described demonstrate a strong spatial awareness combined with a keen knowledge of the slope of the terrain and the behaviour of water across these landscapes. In arid zones such as Bagan, the search for life-sustaining water sources spread across the broad dispersed distribution of villages and associated ritual, monastic and, at times, royal structures. Water management, as underlined by Bagan's easy presumption of rice provision from distant Kyaukse, was not solely irrigation linked to wet rice production - common in other parts of Southeast Asia - but for the cultivation of complementary food sources such as onions and tubers (Moore et al. 2012:144). In the southern wet regions, the focus was on drainage and control to support local rice production and prevent the potentially dangerous flooding of both fields and habitation area during flood times.

Conceptual changes, in particular from interchange with South Asia during the first and early second millennium AD may have encouraged new brick and stone architecture to supplement less durable materials such as wood and thatch, but without effective indigenous systems of water management, urbanism would have failed. The urbanised areas of Myanmar are not, as noted in the introduction, closely akin to those of Angkor where a quest for orthogonal regularity transformed the landscape, masking and often altering the natural regime. A closer parallels to the Myanmar system can be found in the adaptation of urban forms in Central Thailand along the Chao Phraya basin (McGrath et al. 2015).

In both the wet and dry zones of Myanmar, the ancient remains and in many cases, present sustenance of water management is an essential part of interpreting indigenous strategies for water use. We have deliberately detailed water management strategies without aiming to reconstruct their spiritual or political role. Certainly demarcation provided social and political definition, and water was intimately connected with both animistic practice and Buddhist ritual and cannot be separated from the everyday life of Thagara, Kyaikkatha and Bagan. Water management was a basic need in both the high rainfall south and in the arid environment of Bagan. We are not speaking of irrigation and the rise of state, or the incorporation of local meaning into Buddhist kingship, but simply the day to day 
requirements of survival. In areas of moderate rainfall and climate, this is not as obvious, but in our examples, the rainfall and ecologies are extreme. In these extremes, water management becomes a primary means through which the cultural landscape was both made and sustained.

\section{Acknowledgements}

The authors would like to thank the conference organisers for inviting us to participate in Water in Southeast: Navigating Contradiction, Seoul, Korea. We thank Yangon University, SOAS (University of London) and the Nalanda-Sriwijaya Centre, ISEAS Yusof-Ishak Institute for their support. On fieldwork, we thank the Thailand Research Fund through the CRMA (Cultural Relations Mainland Southeast Asia) Project, the Kyoto ASEAN Centre through the EWCC (East-West Cultural Corridor) Project and the Myanmar Archaeology Association.

\section{References}

Acker, Robert 1988. New geographical tests of the hydraulic thesis at Angkor. South East Asia Research 6(1), 5-47.

Aung Myint. 1998. Myanmar She-haung-myo-daw-mya (Myanmar Ancient Cities from Aerial Photos). Ministry of Culture: Yangon.

Aung-Thwin, Michael. 1990. Irrigation in the Heartland of Burma: Foundations of the Pre-Colonial Burmese State. Occasional Paper No 15, Center for Southeast Asian Studies, Northern Illinois University.

Bender, B. 2002. Time and the landscape. Current Anthropology 32(Supplement No. S4, Special Issue Repertoires of Timekeeping in Anthropology), S103-S112.

Charney, Michael. 2004. Southeast Asian Warfare, 1300-1900. Brill: Leiden.

Chit Thein. 1965. Mon Stone Inscriptions (Myanmar version). Yangon.

Cooler, Robert. 1997. Sacred buildings for an arid climate. The Journal of Burma Studies. $1(1), 19-44$.

Cowgill, George. 2004. Origins and development of urbanism: Archaeological perspectives. Annual Review of Anthropology 33, 525-49.

Department of Archaeology. 2003. Report on the Excavation at Bagan Old Palace Site. Department of Archaeology: Ministry of Culture.

Hudson, Bob. 2004. The Origins of Bagan: The archaeological landscape of Upper Burma to $A D$ 1300. PhD thesis, University of Sydney.

Hudson, Bob and Terry Lustig. 2008. Communities of the past: A new view of the old walls and hydraulic system at Sriksetra, Myanmar (Burma). Journal of Southeast Asian Studies 39(2).

Hudson, Bob, Nyein Lwin and Win Maung. 2001. The origins of Bagan: New dates and old inhabitants. Asian Perspectives 40 (1): 48-74.

Kan, Hla. 1977. Pagan: Development and town planning. The Journal of the Society of Architectural Historians. 36(1), 15-29.

Kieffer-Pulz, Petra. 1997. Rules for the sima regulation in the Vinaya and its Commentaries and their application in Thailand. Journal of the International Association of Buddhist Studies, 20(2). 
Lubeigt, Guy. 1998. Pagan, histoire et legendes: Contribution a la geographie historique d'une capitale medievale indochinoise. Paris: Kailash.

E Maung. 1958. Selections from the Inscriptions of Pagan. Yangon: Pyinnya Nanda Press.

McGrath, Brian, Terdsak Tachakitkachorn, Danai Thitakoo. 2015. Bangkok's distributary waterscape urbanism: From a tributary to distributary system. In De Meulder Bruno and Kelly Shannon (eds.), Water Urbanisms East, Emerging Practices and Age-old Traditions, pp. 48-63. Park Books: UFO Explorations of Urbanism.

Moore, E. 1989. 'Water management in early Cambodia: Evidence from aerial photography. The Geographical Journal 155(2), 204-14.

Moore, E. and Aung Myint. 1991 (published 1992) Finger-marked designs on ancient bricks in Myanmar, Journal of the Siam Society 79(2), 81-102.

Moore, Elizabeth and San, Win. 2007. The Gold Coast: Suvannabhumi? lower Myanmar walled sites of the first millennium A.D. Asian Perspectives 46(1), 202-232.

Moore, Elizabeth and Than, Swe. 2006. Early walled sites of Dawei: Thagara and Mokti. In L. Bacus, I. Glover and V. Piggott (eds.), Uncovering Southeast Asia's Past - Selected papers from the Tenth Biennial Conference of the European Association of Southeast Asian Archaeologists, pp. 271-282. Singapore: National University Press.

Moore, Elizabeth, Win, Maung (Tampawaddy) and Htwe Htwe Win. 2013. Ta Mok Shwe-gu-gyi Temple: Local art in Upper Myanmar $11^{\text {th }}-17^{\text {th }}$ century. In M.L. Tjoa-Bonatz, A. Reinecke and D. Bonatz (eds.), Connecting Empires and States: Selected Papers from the 13th International Conference of the European Association of Southeast Asian Archaeologists (Volume 2), pp. 144-160. Singapore: National University of Singapore Press.

Mudar, Karen. 1999. How many Dvaravati kingdoms? Locational analysis of first millennium A.D. moated settlements in central Thailand. Journal of Anthropological Archaeology 18 (1), 1-28.

Ngwe Ngwe Soe. 2000. Thagara-myo-haung-pattama-ah-kyain Tu-paw-thutehthanaloat-ngan-ah-si-yin-kansa ju-hnit 1999-2000 (Thagara Ancient City. First Excavation and Field Survey (1999-2000)). Department of Archaeology. Yangon: Ministry of Culture.

Ni Tut. 2013. Thetso Taung, Yadanabon Annual Magazine. Yangon.

Pelzer, K. J. 1968. Man's role in changing the landscape in Southeast Asia. Journal of Asian Studies 27, 259-279.

Phyo Ngwe Yee. 2011. A Study on the Bagan City Walls and Moats, MA Thesis, 2011

Pichard, Pierre. 1994. Inventory of monuments at Pagan 3(1). Paris: UNESCO; Gartmore: Kiscadale.

San Win. 1986. Sittaung hnit Thanlwin Myit-hnit-thehsat-kya-shi She-myo-haung-myaah pannama letla-kyet (Field Survey of Ancient Sites in the Sittaung and Thanlwin Region). M.A. Thesis. Yangon University.

San Win. 2002. Thuwannabhumi (Thaton) kwin-sin-thutethana-asiyin-kansa 2000 pannama (Suvannabhumi [Thaton] research study). Paper presented to Universities Historical Research Council, Yangon.

San Win. 2005. Mon Pyeh-nyeh Kyaikto hnit Bilin-nyeh-mya Thamaing-thutethanakwin-sin-khayi (Kyaikto and Bilin Township, Mon State: Fieldwork Report). In Myanmar Historical Commission Golden Jubilee Collected Articles. Historical Commission of Education.

Stark, Miriam T. 2015. Southeast Asian urbanism: from early city to classical state. In Norman Yoffee (Ed.). Cities in Comparative Perspective, 4000 BCE - 12000 CE, pp. 74-93. Cambridge: Cambridge University Press. 
Stargardt, Janice, G. Amable G and B. Devereux. 2012. Irrigation is forever: A study of the post-destruction movement of water across the ancient site of Sri Ksetra, Central Burma. In R. Lasaponara and N. Masini (eds.), Satellite Remote Sensing: A New Tool for Archaeology (Vol. 16), pp. 247-267. Dordrecht: Springer Remote Sensing and Digital Image Processing Series.

Than Tun. 1985. Preservation and study of Bagan. In International symposium on the study and preservation of historic cities of South East Asia. Institute of Asian Culture: Sophia University.

Than Tun. 1996. Defacing Old Bagan and Other Articles. Luhtu Press: Mandalay.

Thin Gyi Daw. 1966. The Old City of Bagan. In B.A. Shin, Jean Boisselier and A. B. Griswold (eds.), Artibus Asiae Supplementum 23, Essays offered to G. H. Luce by His Colleagues and Friends in Honour of His Seventy-Fifth Birthday. Volume 2: Papers on Asian Art and Archaeology, pp. 179-188. Ascona, Switzerland: Artibus Asiae Publishers.

Tin Gyi. 1931. Burma Gazetteer, Thaton District. Vol. A. Government Printing and Stationary: Rangoon.

Webb, C. Morgan. 1906. Report on the Settlement Operations in the Tavoy District. Rangoon: Government Printing Press.

UNESCO. 2014. Pyu Ancient Cities: Halin, Beikthano, Sri Ksetra. Nomination of Properties for Inscription on the World Heritage List. (Available at: http://whc.unesco. org/en/list/1444)

Yin Myo Thu. 2011. The Role of King Narapatisithu with Special Reference to the Selected Stone Inscriptions of the Bagan Period. Department of Archaeology, University of Yangon. Unpublished research paper.

Yin Myo Thu. 2013. Religious Dedication of King Narapatisithu. Department of Archaeology: University of Yangon. Unpublished, PhD Dissertation.

Zaw, Win and Myint, Oo. 2013. A Preliminary Study of the Ancient City of Thagara. Dawei University, Department of History. Unpublished, Dissertation Research Paper. 